\title{
New challenges in brand management
}

New challenges in brand management

\section{Nuevos desafíos en la gestión de marcas}

\author{
Cleopatra Veloutsou \\ University of Glasgow, Glasgow, UK, and \\ Elena Delgado-Ballester \\ University of Murcia Facultad de Economia y Empresa, Murcia, Spain
}

\begin{abstract}
Purpose - This paper aims to help in the development of a better understanding of key brand-related terms and discuss the key challenges and trends in brand management.

Design/methodology/approach - This is an editorial based mainly on an extensive and broad literature review on brand management.

Findings - First, this work defines some key brand management terms and presents brand-related issues and concerns that remain unchanged over time. Then it discusses some of the brand management-related matters that are changing since the past few years. Challenges for the management of brands from the side of the companies that have introduced them are then presented. It finally provides a glimpse of the five papers selected for this special issue and then identifies avenues for further research.

Originality/value - This work and the whole special issue together help in the understanding of the dynamic nature of the management of brands over time with implications to the management and the academic engagement with brands.
\end{abstract}

Keywords Brands, Brand management, Brand identity, Brand image, Brand reputation, Brand meaning, Brand co-creation

Paper type Research paper

\section{Resumen}

Propósito - Este artículo tiene como único propósito ayudar en la obtención de una mayor comprensión de conceptos claves relacionados con la marca y presentar los desafíos y tendencias claves en la gestión de ésta.

Diseño/metodología/enfoque - Editorial basado principalmente una extensión y amplía revisión de la literatura relacionada con la gestión de la marca.

Resultados - En primer lugar, este Editorial define algunos conceptos clave de la marca y presenta una serie de cuestiones que han permanecido y permanecen invariables a lo largo del tiempo. Posteriormente, discute otra serie de aspectos y cuestiones que están cambiando en los últimos años para a continuación describir los principales desafíos actualmente existentes para la gestión de la marca desde la perspectiva de

(C) Cleopatra Veloutsou and Elena Delgado-Ballester. Published in Spanish Journal of Marketing ESIC. Published by Emerald Publishing Limited. This article is published under the Creative Commons Attribution (CC BY 4.0) licence. Anyone may reproduce, distribute, translate and create derivative works of this article (for both commercial and non-commercial purposes), subject to full attribution to the original publication and authors. The full terms of this licence may be seen at http:// creativecommons.org/licences/by/4.0/legalcode

Spanish Journal of Marketing

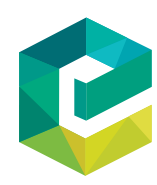


SJME

22,3

las empresas. Este Editorial finaliza con una breve presentación de los cinco artículos seleccionados para este número especial así como una descripción de futuras líneas de investigación.

Originalidad/valor - Este Editorial y en su conjunto todo el número especial dedicado a la marca ayuda a una mayor comprensión de la naturaleza dinámica de la gestión de las marcas a lo largo del tiempo y de sus implicaciones académicas y empresariales.

Palabras clave - Palabras clave Marcas, Gestión de marca, Identidad de marca, Imagen de marca, Reputación de marca, Significado de la marca y co-creación de la marca

Tipo de artículo - Artículo de investigación

\section{Introduction}

Developing strong brands that customers will like, choose and support in multiple ways has been a key objective of most parties that introduce branded offers in various markets (Keller, 2016). The importance of brands as a primary identifier of an offer and a unique "spokesperson" to many publics is widely recognised and brands are seen as key company assets (Mitchell et al., 2001; Davcik et al., 2015). Clearly brands are a source of competitive advantage to the offer (Mitchell et al., 2001) and add value for all parties concerned (de Chernatony and Dall'Olmo Riley, 1998; Veloutsou et al., 2013). However, what the brand represents is often downplayed, and the popular belief is that the brand is primarily a name and a logo, a view that is far from the reality of what the brand really represents.

Brand is a complex entity that gives meaning to the offer it is associated with. It is not surprising that various experts do not seem to agree on what a brand should be defined as (Walker, 2010; Jones and Bonevac, 2013). When asked, academics and practitioners provided a number of different and diverse elements as key identifiers of a brand. Experts suggested that the brand can be approached as a set of characteristics that helps in the tactical and strategic decision-making and the offer's positioning, a set of associations developed from various group's thoughts about the brand, a transaction facilitator and a consumer-brand relationship contributor (de Chernatony and Dall'Olmo Riley, 1998; Mitchell et al., 2001). These statements are broad and represent different aspects of what the brand is and what its functions are. To many people that use the term, it is still unclear what the brand really is and what it represents. Some even argue that the meaning of the term brand differs depending on its use, the user and the audience (Jones and Bonevac, 2013), while researchers see the brand as a constantly evolving concept with high level of complexity (Veloutsou and Guzmán, 2017).

Brand as an entity exists with constituents and conditions that are stable over time and others that are highly dynamic. This work aims to help our understanding of brands and branding as evolved today. It aims to clarify some of the key brand-related definitions, present the more stable and dynamic thinking about the brands and their management and problematize in relation to managerial and academic concerns and priorities related to the current state of brands as entities. In addition to providing a summary of the papers presented in this special issue, this editorial will present some of the things that are the same over time, some of the things that are changing quickly, the challenges for companies that operate in the new conditions and some directions for future research in the area of brand management.

\section{Key brand-related definitions}

Given the complexity and the dynamic nature of brands, it is not surprising that many different approaches and definitions try to capture the term brand (de Chernatony and Dall'Olmo Riley, 1998; Jones and Bonevac, 2013). The most widely adopted definition of the Academy of Marketing that suggests that a brand is "a name, term, sign, symbol or design, or a combination of them, intended to identify the goods or services of one seller from those of competitors" is very limiting and dated. This definition presents the brand as a symbol with a 
primary aim to communicate differentiation. Clearly this approach fails to explain the sources of the differentiation and is far from representing the complex entity that the brand is today.

Today we know that the brand is a "persona" that overlays and includes the offer in terms of its very well defined and measurable functional characteristics of the offer. It is the definition of the offer (Jones and Bonevac, 2013), the sum of fundamental values and attributes ascribed to it by various audiences. It goes over and above the offer's symbols and images and it has become an entity that consumers construct from these symbols and images. Therefore, the brand will be defined in this work as:

[...] an evolving mental collection of actual (offer related) and emotional (human-like) characteristics and associations which convey benefits of an offer identified through a symbol, or a collection of symbols, and differentiates this offer from the rest of the marketplace.

Given that the brand can be perceived differently depending on the audience (Jones and Bonevac, 2013), it seems that it is not enough to define the term brand, but there is a need to better explain how the brand is considered from different audiences. Terms that are extensively used to represent what the brand is like "brand identity", "brand image", "brand reputation" and "brand meaning" are used interchangeably, and though no consensus exists on their real essence (de Chernatony, 1999; Csaba and Bengtsson, 2006; Walker, 2010), in general, branding researchers agree that all these terms describe the brand, but they also differ because they describe as connived from different groups of individuals or/and at different points in time. A clear definition of these terms is paramount to further engage with any brand-related discussion.

Brand identity represent an internal perspective of the brand (Balmer and Greyser, 2006), and it is representing the understanding of the brand that the managerial team and any other stakeholders supporting the brand development share. Therefore, as informed from relevant literature (Aaker, 1996; Coleman et al., 2011; Black and Veloutsou, 2017), brand identity is defined here as:

[...] the symbols and the set of the brand associations that represent the core character of the brand that the team supporting the brand aspire to create or maintain as identifiers of the brand to other people.

Brand image and brand reputation are related to the views that external stakeholders and audiences form about the brand (Walsh and Beatty, 2007; Walker, 2010; Siano et al., 2011; Black and Veloutsou, 2017). Brand image is seen here as:

$[\ldots$. . the perception formed to the mind of a member of the external audience about the brand after one real or mental encounter with the brand". Brand reputation derives from the accumulation of brand images and is approached here as "an aggregate and compressed set of public judgments about the brand.

Brand meaning reflects internal and external stakeholders' mind-set about a brand (Vallaster and von Wallpach, 2013) and, therefore, the term primarily incorporates both brand identity and brand reputation as well as brand image. Other terms have also been used to reflect the same concepts (Urde, 2016), but the clarification of all these terms goes beyond this editorial.

In the remainder of this work the terminology used will reflect the provided terms.

\section{Things that remain the same}

Some characteristics in the context of brand management have stayed the same for the past decades. The most prevalent element is that there are primarily two key parties that are involved and interested in brands when we think about their presence in the market: companies and customers. Each of these two main brand-interested parties try to achieve their own objectives that have significant dissimilarities.
New challenges in brand management 
SJME

22,3

Companies want strong brands that are assets and try to increase the strength of the brand and lead to favourable assessment and brand support from various groups, such as consumers and employees, providing market power (Davcik et al., 2015; Dwivedi et al., 2015; Poulis and Wisker, 2016). Developing brands with strong and favourable reputation is expected of the companies and their network of stakeholders (Aaker, 1991; Keller, 1993; Christodoulides and de Chernatony, 2010; Keller, 2016). Nurturing clear, strong and unique associations will improve the assessment of the brands in the mind of consumers, promote brand differentiation, facilitate the expansion of the company via means such as increase of sales of introduction of new products. For all these reasons, brand association development is one of the key priorities of companies (Chatzipanagiotou et al., 2016; Keller, 2016), and it is what companies try to achieve in all the markets they are operating in (Christodoulides et al., 2015). Companies aim to build commitment and loyalty and repeat purchase via brands (Veloutsou, 2015; OsunaRamírez et al., 2017), and see brands as income streams and try to measure the financial strength of the brand (Davcik et al., 2015; Nguyen et al., 2015). A clear and distinct position in consumers' minds that make them feel and think positively about the brand transforms the brand into a clear corporate asset (Keller, 1993; Mitchell et al., 2001; Veloutsou et al., 2013; Keller, 2016). It is paramount in our understanding of the strength of the brand to move away from the historical approach used to assess brands and to evolve our thinking by considering over and above the past performance of a brand its predicted performance and its ability to generate future income flows, such as market brand equity (Schultz, 2016). From company side, brand is also seen as a protected property in terms of the characteristics of its symbol, and brand identity supports internal decision-making because it provides ongoing affirmation of the purpose of the brand and provides organisational alignment (de Chernatony and Dall'Olmo Riley, 1998; Mitchell et al., 2001) while leading to stronger recruitment of new staff (Saleem and Iglesias, 2016).

For many years we have known that, in addition to saving time for search, consumers want to buy and use brands to gain certain psychological rewards. Individuals satisfy their functional, emotional, personal and social needs through the value these brands offer to them (Sheth et al., 1991), a view still widely accepted in the literature (DelgadoBallester and Fernández-Sabiote, 2015; Palazón et al., 2015; Ruane and Wallace, 2015; Simon et al., 2016). Functional value is the extent to which an offer performs a desired function (Palazón et al., 2015); emotional value represents the overall assessment of the benefits and sacrifices; and social value represents the degree that the offer helps the individuals to associate with one or more specific social groups (Sheth $e$ t al., 1991). When the brand delivers the appropriate performance and quality, it is generally a brand that consumers have a tendency to engage to a relationship with (Hess et al., 2011). Individuals will have the willingness to consume brands that meet their expectations and maximize the overall utility they get through these brands. Consumers also want to use brands that have the appropriate functional and imaginary characteristics that can help them express who they are. They look forward to admire and find brands they can relate with (Fournier, 1998; Veloutsou, 2007), they assess brands, they develop feelings and form relationships with brands that vary in duration (Huber et al., 2015) and they express their brand feelings through their behaviour (Veloutsou and Moutinho, 2009; Veloutsou, 2015; Giovanis, 2016). This is an ongoing process in the lives of most consumers that starts from a very young age (Veloutsou and McAlonan, 2012), and they look for these brands to allow them to relate both with the brand itself and with other consumers because of the brand (Veloutsou, 2009; Dessart et al., 2015, 2016).

What is also known is that different stakeholders have different mental associations related to the brand. The brand meaning can be very diverse depending on the individual or 
the group that experiences the brand meaning. The view of the people who internally support the brand primarily and try to convey it externally (brand identity) is far more complex and has a greater detail in the associations rather than the view that is formed after one interaction (brand image) or the overall evaluation of the brand (brand reputation) in the minds of a member of an external audience. This is because of the dissimilar information and experiences that individuals might have about the brand and the differences in the processing and the assessment of the information and experiences.

\section{Other things have changed}

Although the basic approach of bringing together supply and demand and ensuring that sellers and buyers are happy and engaging in their exchanges, the way that these exchanges have materialised in the past few years has changed. There are a number of changes that influence the way that the brands are perceived, produced, purchased and consumed, as well as their role in the lives of the various stakeholders groups.

What is considered as a brand has changed over the years (Veloutsou and Guzmán, 2017). Now consumers and companies do not see only products and services as brands, but many other entities are also approached as branded entities. Humans in the form of celebrities (Kowalczyk and Pounders, 2016), politicians (Guzmán et al., 2015; Bigi et al., 2016), artists (Kucharska and Mikołajczak, 2018), managers (Bendisch et al., 2013) and celebrity CEOs (Scheidt et al., 2018), athletes (Carlson and Donavan, 2013), bloggers (Delisle and Parmentier, 2016) or as simple individuals (Guzmán et al., 2015) see themselves and are seen by others as brands in their own right. Countries, regions and cities are also seen as brands (RojasMéndez, 2013) and they are very complex in their makeup and approach.

In the past we used to think that the brand is an entity developed through a process primarily coordinated from the company and offered to the market (Veloutsou and Panigyrakis, 2001). Company employees were expected to manage brand meanings by developing and supporting brand identities (Harris and de Chernatony, 2001; Urde, 2016) and values (Kapferer, 2008) over time to the extent that some suggested that a framework with steps can be used to support the brand building effort (Centeno et al., 2013). Consumers had to be trained on what the brands mean, and the reputation of the brand in the minds of various external audiences was very much dependent on the elements of the internal brand identity that the brand support team had chosen to communicate to the market.

Brands today are independent entities in their own right, to the extent that they have been anthropomorphised (Aaker, 1997; Geuens et al., 2009; Azar, 2015; Delgado-Ballester et al., 2017), even in business-to-business markets (Veloutsou and Taylor, 2012). There is immense engagement in the literature in the latest developments of the phenomenon (Davies et al., 2018; Kumar, 2018; Rander, 2018). This is because brands develop their credibility and trustworthiness in the minds of the external audiences (Delgado-Ballester and MunueraAlemán, 2001; Li et al., 2015; Hegner and Jevons, 2016) that originate from information and impressions about the brand that come from multiple channels. The relationships consumers form with brand can become very strong and have positive nature expressed through brand love (Batra et al., 2012; Huber et al., 2015; Vernuccio et al., 2015; Karjaluoto et al., 2016; DelgadoBallester et al., 2017; Hegner et al., 2017a) or be negatively presented as brand hate (Zarantonello et al., 2016; Hegner et al., 2017b; Zarantonello et al., 2018), brand aversion (Park et al., 2013) or brand sabotage (Kähr et al., 2016). This extreme passion that often leads to actions (Wallace et al., 2014; Zarantonello et al., 2016) is a phenomenon which is becoming increasingly encountered, especially when they are negative and can turn against the brand.

The developments of a brand's mental connection as a part of the brand meaning in the minds of various groups of stakeholders (brand identity and brand reputation) are generated and
New challenges in brand management 
SJME

22,3

maintained involving more players than ever. Brand reputations are informed over time by images captured through company-controlled and -uncontrolled signalling (Walker, 2010) and the input of uncontrolled or semi-controlled signalling is increasing. The views of managers in various personal matters influence brand reputation if they become public (Leak et al., 2015). In all sectors, consumers from passive observers have become active contributors to the development of the brand and its functional characteristics (Kristal et al., 2016) and its meaning (Black and Veloutsou; 2017), both when new offers are introduced and when existing offers are adjusted. Consumers want to actively contribute and co-create their desired brands (Kennedy, 2017) to the extent that co-creation managers are advised to consider co-creation as the attributions that consumers have about the brand (Kennedy and Guzmán, 2017). Starting from a very young age (Iyer et al., 2016; Rodhain and Aurier, 2016), consumers talk amongst themselves, interact with others in brand-related issues independently or at a collective level within social groups like the family (Iyer et al., 2016), their friends (Palazón et al., 2015), informal groups (Veloutsou and Moutinho, 2009) or in groups with more formally constituted forms in brand communities (Dessart et al., 2015; Cova and Paranque, 2016; Kaufmann et al., 2016; Pasternak et al., 2017). Consumers live the brands and want to share their individual feelings with others (Veloutsou and Moutinho, 2009; Veloutsou, 2009; Dessart et al., 2015; Pasternak et al., 2017), and research reports that they develop social links with the other members of brand communities and loyalty to the community itself (Hook et al., 2018). By participating in brand communities, individuals often express or even develop their individual identity through their active engagement with the brand and the other people who also admire the same brand (Black and Veloutsou, 2017).

Although consumers and customers seem to be the most significant contributors in the development of the brand and its meaning, they are not the only stakeholders involved in the brand meaning-creation network (Vallaster and von Wallpach, 2013). Since a very long-time advertising and other communication agencies have been playing a key role in brand creation (Veloutsou and Panigyrakis, 2001). Business partners, such as retailers and suppliers, are actively playing roles with the aim of contributing to the development of the brand identity and the decisions made in the brand team (Törmälä and Saraniemi, 2017). Linked entities, such as endorsers (Dwivedi et al., 2015), other brands (Davies et al., 2006; Delgado-Ballester and Hernández-Espallardo, 2008; Thomas, 2015) or products are sold under the same brand name, such as own labels (Marques dos Santos et al., 2016) and the country or origin (Lu and Xu, 2015; Yousaf and Li, 2015; Brodie and Benson-Rea, 2016). What the press and the media report about the brand and all the publicity produced by what is perceived as reliable sources are not unnoticed when consumers evaluate brands (Gendel-Guterman and Levy, 2017). The various stakeholders may see the brand differently from one another (Pino et al., 2015). Other brands and events associated with the brands are also influencing the brand meaning, with various activities ranging from co-branding (Ho et al., 2017) to placing brands in games (Vashisht and Pillai, 2017). Brand images are not produced primarily from the selected components of the brand identity that the company decides to project to the market and produce images to shape brand reputation. Brand reputation is extensively informed from inputs that are uncontrolled by the company (Figure 1). We are moving from the monolithic brand building originating from the company to a conversational branding that involves many contributors (Veloutsou and Guzmán, 2017).

In consumer markets, the brand consumption has also changed, in terms of the requirements and expectations from the side of individual consumers and their interaction with the brands. Consumers when thinking about brands are interested in not just the objects but in the total experience that the brand can offer them (Morgan-Thomas and Veloutsou, 2013), in terms of both hedonic and functional brand experiences (Merrilees, 2016). The experiential value that consumers receive from the brand appears to have become increasingly influential over the functional value in moving consumers to act (Delgado-Ballester and Fernández-Sabiote, 2015). 


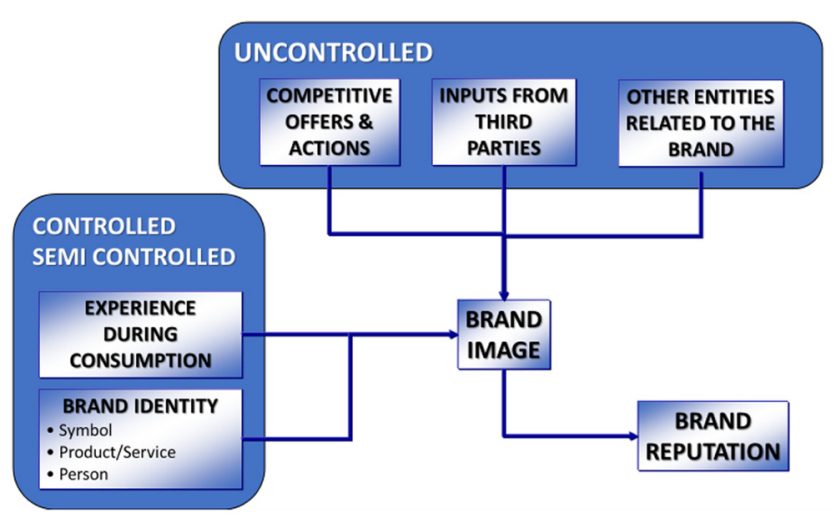

New challenges in brand management

261

Experiences have become a key element in understanding the way that consumers understand, assess and react to brands (Andreini et al., 2018). Individuals engage a variety of senses to interact with the brand and assess it (Baxter et al., 2015), and sometimes, they even want to cocreate these experiences (Rialti et al., 2018). It is not uncommon for consumers to feel the need to share their experiences and stories in a way that influence the understanding of others about the brands (Hughes et al., 2016). It is known that a positive sensory brand experience strengthens the brands in the minds of consumers both directly and indirectly, through consumer engagement (Hepola et al., 2017), and leads to loyalty (Brakus et al., 2009) and equity (Mishra et al., 2014; Castañeda-García et al., 2018).

A number of consumers today decide not to just buy or use brands but to engage with them. Brand engagement is not a rare phenomenon and it signifies the importance of a brand to the consumers who decide to engage with it. When engaging with a brand, consumers want to come close and interact with their desired brand. Therefore, consumer brand engagement is a complex phenomenon that goes over and above visible interaction and has cognitive, emotional and behavioural components (Brodie et al., 2013; Dessart et al., 2015, 2016; Dessart, 2017). Clearly brand engagement is key when consumers have input in the co-creation of brands and brand meaning (Brodie et al., 2011), and it leads to various benefits for the company including brand trust, brand commitment and brand loyalty (Dessart, 2017). Although the interaction can happen face to face (Black and Veloutsou, 2017), most of the engagement is happening in online settings and often in social media (Dessart et al., 2015, 2016; Tafesse, 2016). This is because of the convenience that these settings provide, which is another indication of the power of technology on the shaping of brands in the current environment.

Contrary to what academia discussed at large, some signals from the market suggest the opposite. Research findings from the industry support that there is a huge general disaffection and disconnection between consumers and brands that it is not particular to a specific country or consumer segment and market. For example, the most worldwide recognized global survey Meaningful Brands ${ }^{\circledR}$ (2018) conducted by Havas Media with 1,500 global brands in 15 different industries and more than 300,000 interviews demonstrates that the vast majority of brands are meaningfulness because they do not provide significant personal, collective or functional benefits to their lives. As a result of this meaningfulness, in 2017, 74 per cent of consumers in the world would not care if brands disappear, and in 2013, the percentage was almost at the same level (73 per cent). Across geographical areas, the survey indicates that in Western Europe, North America and East Asia and Australia, the percentage of brands that are trusted 
SJME

22,3

varies from 25 per cent to 33 per cent, while in Latin America and Southeast Asia, this percentage is higher at 79 per cent and 81 per cent, respectively.

\section{Challenges for the brand management from the company perspective}

Companies have to operate and try to profit in the environment that has changed. Brand management teams have to work harder than ever to coordinate the brand building and support efforts and produce results (Dunes and Pras, 2017). Clearly brands cannot be managed through a well-structured and pre-determined process like the way that one would run a factory or operate a garbage disposal (Schultz and Schultz, 2004).

While some research suggests that brand management teams still have most of the control and a strong influence in the development and management of brand meaning (Urde, 2016), other research studies argue that the branding process has been transformed and the control of brand meaning has been mostly surrendered as brands are co-created with agents that do not work in the company (Cova and Paranque, 2016). The latter seems to be the case, and brands cannot belong, in a psychological sense of ownership, to any one or any firm. It is not just employees working in various positions and not direct members of the brand management team contributing to the formation of the brand meaning (Indounas and Arvaniti, 2015; Kaufmann et al., 2016) but often multiple stakeholders who develop a network of relationships. Brand teams realise that they increasingly lose control on the brand-building and brand-support processes. Brand management teams and their internal leaders are no longer in a position to unilaterally define and control brand meaning, but they need to perceive themselves as one actor among many (Vallaster and von Wallpach, 2013). The brand meaning is often negotiated and formed with the intensive input of other stakeholders (Black and Veloutsou, 2017).

Brand teams find it difficult to think about the integration of other players in the brand team. There are some attempts to work with various external agents to support brand building. The most notable attempt that some companies engage with are groups of consumers in terms of brand communities that could help in the development of the brand as a product or brand reputation (Black and Veloutsou, 2017). However, the majority of the companies neglect the need to support the brand network that includes other stakeholders in the system.

Brands need to meet a wide variety stakeholder needs involved in creation and consumption of these brands. For example, place brand is formed from inputs of the country and local authorities as well as all the actions of the people involved in the service of the place, from the taxi drivers to street cleaners. A place brand can be seen as a tourist destination brand (Pino et al., 2015; Rojas-Méndez et al., 2015; Balmer and Chen, 2016;), a place to invest (Papadopoulos et al., 2016), a place to work (Pino et al., 2015) or a place to live (Kemp et al., 2012; Hakala et al., 2015; Pino et al., 2015). Brands can be used to support the selling of the brand, but employers also have to use their brands that attract employees (Sivertzen et al., 2013). Different audiences are assessing the same brand from discrete perspectives and they expect the brand to be able to satisfy their needs, which can be dissimilar from the needs of other groups that are also assessing the brand. When a brand is developed, the input of the various contributors is diverse and the demands of different involved groups in one sector are complex. The diversity and complexity in the processes associated with the brand make the management of brands and the support of a somewhat homogeneous, for all the parties involved, brand meaning a very difficult, if not impossible, task.

The environment is changing and becoming increasingly global faster than ever. The brand support team from the company side seems to not be able to cope with the speed of change. Markets have become more global, brands have become diffused across borders and cultures (Frank and Watchravesringkan, 2016) and the technological advances have enhanced the cultural borrowing and the interaction of interested parties across the globe. The wide use of the internet 
and social networks such as Facebook, Twitter, Instagram and Pinterest facilitates the process of consumers finding likeminded individuals that support the brands they like without any constrain of geographic boundaries (Dessart et al., 2015; Simon et al., 2016; Tafesse, 2016). Technology has played an important role in how consumers experience brands, as research in internet and social media context has proven (Dessart et al., 2015; Vernuccio et al., 2015).

One of the consequences of the facilitation of communication and the social media seems to be the ability of many to voice their assessments and feelings about the brands and reach a wide audience. Brand support teams try to find ways to more effectively manage crises New challenges in brand management situations (Jeon and Baeck, 2016), negative publicity (Gendel-Guterman and Levy, 2017), fake news (Berthon et al., 2018), online firestorms or collaborative brand attacks (Rauschnabel et al., 2016), brand sabotages (Kähr et al., 2016) and different types of negative engagement that consumers may have with a brand (Hollebeek and Chen, 2014), such as negative consumer reviews (Ullrich and Brunner, 2015), with an emphasis on adjusting to negative events depending on their nature (Liu et al., 2018). Developing skills to better handle publicity and reputation-damaging situations depending on the type of the crisis and the prior attitude of consumers towards the brand is vital for the prosperity of brands.

In today's world, it is difficult for companies and brand teams to find ways to support their brands and secure long-term prosperity of the brand that can secure future income streams. Although many parties "owns" a piece of a brand, firms that have the legal ownership of the symbol get first claim on the financial returns. Brands that will not manage to produce enough income to pay a dividend to the owners or the managers will probably be removed from the marketplace. Most companies for years focus on the tactics, operation, every-day running of the business and the implementation of programs that can bring short-term financial results. This includes the adoption of new technologies and tactics, such as storytelling via the webpages (Delgado-Ballester and Fernández-Sabiote, 2016), without detailed assessment of the suitability that these methods have for the context and the brand. However, it seems that there is still limited strategic thinking related to the future development of brands.

Brands that lose their clear and relevant positioning are expected to fade and die. Securing that there is consistency amongst the views of all of them is of crucial importance for any organization (Biedenbach and Manzhynski, 2016; Saleem and Iglesias, 2016). However, brand managers cannot control the process as such, but they can try to coordinate the brand support and in some occasions they become observers of the changes that other stakeholders impose to the brand reputation.

A cultural change is needed that should help brands flourish in highly uncertain and everchanging conditions. Brand management teams need to remember that consumers only reward those brands that provide them with the desired type of functional, emotional, personal or social value. This very basic principle remains the same. What changes over time is how consumers assess value and this is a big challenge in the current dynamic environment. The same brand management teams also have to accept that from brand guardians, they have become brand hosts, and very many internal and external stakeholders need to be influenced to help the development and the signalling of the brand to other audience as consistently as possible. Adopting complex scenario planning might help the brand team prepare for some of the uncertain and unpredictable conditions that brands may phase.

All in all, to make more meaningful connections between consumers and brands, managers have to go to the basics: understanding what matters most to people and what they expect from brands, such as healthy lifestyles, improving the environment, connectivity with relatives and friends, saving time or making their lives easier and happier. Without this knowledge building brand content and experiences and the appropriate mix of touch-points with the brand is pointless. 
SJME

22,3

\section{This special issue}

With this in mind, in 2017, the Spanish Journal of Marketing announced a call for papers for this Special Issue based on the challenges in brand management. The aim of this Special Issue was to stimulate a substantial contribution to the better understanding of the developments and the directions of the brand management research and practice. In total, 17 papers were submitted. The papers that were eventually accepted went through a review process and they were read by reviewers at least twice. On that basis, 5 manuscripts from the original 17 submissions were accepted for publication in this Special Issue, less than a third of the original submissions.

The five articles of this special issue on new challenges in brand management include different context settings, methodologies and topics relevant to the understanding and management of brands. They include lovemark measure for high-technology products, determinants of store brands purchase and penetration, an extended brand equity model, customer identification and engagement with hospitality brands and political brand personality. All these papers have been written by scholars from Egypt, Greece, India, Malaysia and the UK, which reflect the international interest attached to branding themes.

The paper by Giovanis and Athanasopoulou entitled "Understanding lovemark brands: dimensions and effect on brand loyalty in high-technology products" is the first methodological and empirical contribution that develops and validates a lovemark measure that captures consumers' perceptions of both functional (i.e. brand respect) and emotional (i.e. brand love) brand aspects. Findings from a large sample of 1,016 consumers of high-technology products demonstrate the theoretical and nomological validity of the proposed measure to better explain three loyalty manifestations. Interestingly, a key insight from this study is the utility of the measure to classify brands using the lovemark grid proposed by Roberts (2004) to better identify lovemarks. As such, managers should take cognisance of this methodological tool because it could be useful to track the positioning of their brands in the lovemark grid to better improving consumers' experience with the brands through brand respect and love.

The second article by Jain, Chawla, Ganesh and Pich entitled "Exploring and consolidating the brand personality elements of the political leader" integrates the models of Aaker (1997) and Caprara et al. (2001) to propose a new framework that helps in developing political brand personality. The novelty of this article resides not only in the context setting (i.e. political marketing) but also in the identification of key traits of brand personality that might help a political leader to enhance the relationship with its voters.

In the third article entitled "Promoting customer brand engagement and brand loyalty through customer brand identification and value congruity", Rather, Parrey and Tehseen use congruity and social identity theories to propose antecedents of brand engagement that go beyond company-based and traditional customer-based drivers such as value congruity and brand identification. Based on research findings, a number of management practices for hospitality brand marketers are proposed to develop strong and long-term relationships with customers.

The final two articles focus on store brands, an issue that never loses interest among researchers because of its importance for the retailing industry in profitability and its effects on strategic reactions of national-brand manufacturers. Specifically, the originality of the fourth article "Factors affecting consumers' willingness to buy private label brands (PLBs): applied study on hypermarkets" by Mostafa and Elseidi, resides in context setting of the study because the authors analyse how consumers' perceptions directly and indirectly affect their willingness to buy private label brands of hypermarkets and supermarkets in a developing market (Egypt) which is relatively new in introducing and developing private brands. The authors offer suggestions for international retailers being interested in entering Middle Eastern countries like Egypt. 
For its part, the fifth article "Store brand adoption and penetration explained by trust", Sarantidou focuses on a different factor to those analysed by Mostafa and Elseidi, when explaining store brand purchases. With a sample of 904 respondents and sample variety of food and non-food products, this study reveals that trust is a central driver of store brand purchases, and the levels of trust vary across different retailers and product categories. Having said that, interesting managerial implications are derived for both retailers and manufacturers of national brands.

These papers indeed give important insights on the issues that are of great interest for brand management, are dynamic and need further investigation. We hope that the papers in this special issue will be meaningful enough to satisfy the interest of the readers, the researchers and brand managers.

\section{Directions for research in brand management}

An account on the trends in the research themes in brand management research and lot of clear research directions in the area were recently provided in a paper that had exactly this focus (Veloutsou and Guzmán, 2017).

Clearly one would ask for more research on the areas that are emerging and the developments. This includes the co-creation, the intensive feelings, the effects of brand anthropomorphism and other relevant conceptual developments. Challenges from the environment and its dynamics, such as research on technology and its advancement and the effects of globalisation on brands, are also of interest to existing research.

Future research should not neglect issues related to relatively stable constituents and conditions and try to assess how they are influenced from the changes in other factors. We need to know how they adjust over time and how they are affected from changes on the more dynamic elements of the environment.

An area that has received relatively limited attention in the past few years and is needed relates to the internal practices for keeping the coordination of the brand development. Given that the brands receive ever-increasing input from a wide network of contributors, the roles of these contributors, the processes that can be used to support the brand building and others relevant to this theme issues should be on the top of the agenda for researchers in the future.

The last area that needs attention from academics is the further exploration of the possibility that brands are losing altogether their function and that they majority of brands might disappear. The strong message that some of the industries try to convey clearly needs far more attention. If there is some evidence that this can be the reality, then research should look for advice to practice that can secure that brands can develop relevance for the market meaning and can and will stay in the group of brands that will remain in the market.

\section{Conclusion}

Academic research is trying to keep on top of the developments, capture and present reality as accurately as possible, often adopting new data collection and data analysis methods to increase objectivity (Veloutsou and Guzmán, 2017). The brand-related developments reflect the trends in the society. Brands are powerful social drivers that give meanings and identity to what individuals use and buy helping them to build their own self-identity. Through brands, individuals express themselves in the society and convey their status and prestige in a language recognized and understood by others. Brands are also adding value-economic agents for the firms that introduce them. The growing interest in brands, the increasing desire to co-create them and the constant changes on what they represent echo the reality that we are living in and the increased acceptance of diversity that consumers experience via the interactions with dissimilar to them individuals. 
This Special Issue comprises five papers plus an extended editorial on contemporary issues related to brands as seen from various stakeholders and their management. As guest editors, we hope that you will enjoy the content and you will find it mind-provoking. We certainly think that the work included in this issue is a small contribution to our better understanding of the complex and ever-changing landscape of brand management and that both academics and practitioners should continue their engagement with the area and they will not just continue but enhance their exchanges that could facilitate the overall understanding of the changes in the context and the conditions. This is really the only strategy that can facilitate quicker response to the developments that may lead to decisions and adoption of practices that can benefit all the parties in the brand network involved, primarily the companies and their customers but also other stakeholders.

We want to express sincere thanks to the authors and the knowledgeable and hardworking reviewers, and those others who have been directly or indirectly associated and involved with this special issue. Special thanks to the Editor who provided a lot of guidance and leadership to the Spanish Journal of Marketing, Carlos Flavian, the Editorial Board of the Journal and the whole publishing team at Emerald for their ongoing support for academic publishing and scholarly research in the field of marketing.

\section{References}

Aaker, D.A. (1991), Managing brand equity: capitalizing on the value of a brand name, The Free Press, New York, NY.

Aaker, D.A. (1996), Building Strong Brands, Free Press, London.

Aaker, J. (1997), “Dimensions of brand personality”, Journal of Marketing Research, Vol. 34 No. 3, pp. 347-356.

Andreini, D., Pedeliento, G., Zarantonello, L. and Solerio, C. (2018), "A renaissance of brand experience: advancing the concept through a multi-perspective analysis", Journal of Business Research, Vol. 91, pp. 123-133.

Azar, S.L. (2015), "Toward an understanding of brand sexual associations", Journal of Product and Brand Management, Vol. 24 No. 1, pp. 43-56.

Balmer, J.M.T. and Chen, W. (2016), "Corporate heritage tourism brand attractiveness and national identity", Journal of Product and Brand Management, Vol. 25 No. 3, pp. 223-238.

Balmer, J.M.T. and Greyser, S.A. (2006), "Corporate marketing: integrating corporate identity, corporate branding, corporate communications, corporate image and corporate reputation", European Journal of Marketing, Vol. 40 Nos 7/8, pp. 730-741.

Batra, R., Ahuvia, A. and Bagozzi, R.P. (2012), "Brand love”, Journal of Marketing, Vol. 76, pp. 1-16.

Baxter, S.M., Ilicic, J., Kulczynski, A. and Lowrey, T. (2015), "Communicating product size using sound and shape symbolism”, Journal of Product and Brand Management, Vol. 24 No. 5, pp. 472-480.

Bendisch, F., Larsen, G. and Trueman, M. (2013), "Fame and fortune: a conceptual model of CEO brands", European Journal of Marketing, Vol. 47 Nos 3/4, pp. 596-614.

Berthon, P.R., Treen, E.R. and Pitt, L.F. (2018), "How truthiness, fake news and post-fact endanger brands and what to do about it", GfK Marketing Intelligence Review, Vol. 10 No. 1, pp. 18-23.

Biedenbach, G. and Manzhynski, S. (2016), "Internal branding and sustainability: investigating perceptions of employees", Journal of Product and Brand Management, Vol. 25 No. 3, pp. 296-306.

Bigi, A., Treen, E. and Bal, A. (2016), "How customer and product orientations shape political brands", Journal of Product and Brand Management, Vol. 25 No. 4, pp. 365-372.

Black, I. and Veloutsou, C. (2017), "Working consumers: co-creation of brand identity, consumer identity and brand community identity", Journal of Business Research, Vol. 70, pp. 416-429. 
Brakus, J., Schmitt, B. and Zarantonello, L. (2009), "Brand experience: what is it? How is it measured? Does it affect loyalty?”, Journal of Marketing, Vol. 73 No. 3, pp. 52-68.

Brodie, R.J. and Benson-Rea, M. (2016), "Country of origin branding: an Integrative perspective", Journal of Product and Brand Management, Vol. 25 No. 4, pp. 322-336.

Brodie, R.J., Hollebeek, L.D., Juric, B. and Ilic, A. (2011), "Customer engagement: conceptual domain, fundamental propositions, and implications for", Research", Journal of Service Research, Vol. 14 No. 3, pp. 252-271.

Brodie, R.J., Ilic, A., Juric, B. and Hollebeek, L. (2013), "Consumer engagement in a virtual brand community: an exploratory analysis", Journal of Business Research, Vol. 66 No. 1, pp. 105-114.

Carlson, B.D. and Donavan, D.T. (2013), "Human brands in sport: athlete brand personality and identification", Journal of Sport Management, Vol. 27 No. 3, pp. 193-206.

Castañeda-García, J.A., del Valle-Galindo, A. and Martínez-Suárez, R. (2018), "The effect of online and offline experiential marketing on brand equity in the hotel sector", Spanish Journal of Marketing ESIC, Vol. 22 No. 1, pp. $22-41$.

Centeno, E., Hart, S. and Dinnie, K. (2013), "The five phases of SME brand-building", Journal of Brand Management, Vol. 20 No. 6, pp. 445-457.

Chatzipanagiotou, K., Veloutsou, C. and Christodoulides, G. (2016), "Decoding the complexity of the consumer-based brand equity process", Journal of Business Research, Vol. 69 No. 11, pp. 5479-5486.

Christodoulides, G. and de Chernatony, L. (2010), “Consumer-based brand equity conceptualisation and measurement", International Journal of Market Research, Vol. 52 No. 1, pp. 43-66.

Christodoulides, G., Cadogan, J. and Veloutsou, C. (2015), "Consumer-based brand equity measurement: lessons learned from an international study", International Marketing Review, Vol. 32 Nos 3/4, pp. 307-328.

Coleman, D., de Chernatony, L. and Christodoulides, G. (2011), "B2B service brand identity: scale development and validation", Industrial Marketing Management, Vol. 40 No. 7, pp. 1063-1071.

Cova, B. and Paranque, B. (2016), "Value slippage in brand transformation: a conceptualization", Journal of Product and Brand Management, Vol. 25 No. 1, pp. 3-10.

Csaba, F.F. and Bengtsson, A. (2006), "Rethinking identity in brand management", in Schröder, J.E. and Mörling, M. (Eds), Brand Culture, Routledge, London, pp. 118-135.

Davcik, N.S., Vinhas da Silva, R. and Hair, J.F. (2015), "Towards a unified theory of brand equity: conceptualizations, taxonomy and avenues for future research", Journal of Product and Brand Management, Vol. 24 No. 1, pp. 3-17.

Davies, F., Veloutsou, C. and Costa, A. (2006), "Investigating the influence of a joint sponsorship of rival teams on supporter attitudes and brand preference", Journal of Marketing Communications, Vol. 12 No. 1, pp. 31-48.

Davies, D., Rojas-Méndez, J., Whelan, S., Mete, M. and Loo, T. (2018), "Brand personality: theory and dimensionality", Journal of Product and Brand Management, Vol. 27 No. 2, pp. 115-127.

de Chernatony, L. (1999), "Brand management through narrowing the gap between brand identity and brand reputation", Journal of Marketing Management, Vol. 15 No. 1/3, pp. 157-179.

de Chernatony, L. and Dall'Olmo Riley, F. (1998), "Defining a 'brand': beyond the literature with experts' interpretations", Journal of Marketing Management, Vol. 14 No. 5, pp. 417-443.

Delgado-Ballester, E. and Fernández-Sabiote, E. (2015), "Brand experimental value versus brand functional value: which matters more for the brand?”, European Journal of Marketing, Vol. 49 Nos 11/12, pp. 1857-1879.

Delgado-Ballester, E. and Fernández-Sabiote, E. (2016), “Once upon a brand': storytelling practices by Spanish brands", Spanish Journal of Marketing - ESIC, Vol. 20 No. 2, pp. 115-131.

Delgado-Ballester, E. and Hernández-Espallardo, M. (2008), "Building online brands through brand alliances in internet”, European Journal of Marketing, Vol. 42 No. 9/10, pp. 954-976.

New challenges in brand management 
Delgado-Ballester, E. and Munuera-Alemán, J.L. (2001), "Brand trust in the context of consumer loyalty”, European Journal of Marketing, Vol. 35 Nos 11/12, pp. 1238-1258.

Delgado-Ballester, E., Palazón, M. and Pelaez-Muñoz, P. (2017), "This anthropomorphised brand is so loveable: the role of self-brand integration”, Spanish Journal of Marketing - ESIC, Vol. 21 No. 2, pp. 89-101.

Delisle, M.P. and Parmentier, M.A. (2016), "Navigating person-branding in the fashion blogosphere", Journal of Global Fashion Marketing, Vol. 7 No. 3, pp. 211-224.

Dessart, L., Veloutsou, C. and Morgan-Thomas, A. (2015), "Consumer engagement in online brand communities: a social media perspective", Journal of Product and Brand Management, Vol. 24 No. 1, pp. 28-42.

Dessart, L., Veloutsou, C. and Morgan-Thomas, A. (2016), "Capturing consumer engagement: duality, dimensionality and measurement", Journal of Marketing Management, Vol. 32 Nos. 5/6, pp. 399-426.

Dessart, L. (2017), "Social media engagement: a model of antecedents and relational outcomes", Journal of Marketing Management, Vol. 33 Nos 5/6, pp. 375-399.

Dunes, M. and Pras, B. (2017), "The impact of the brand management system on performance across service and product-oriented activities", Journal of Product and Brand Management, Vol. 26 No. 3, pp. 294-311.

Dwivedi, A., Johnson, L.W. and McDonald, R.E. (2015), "Celebrity endorsement, self-brand connection and consumer-based brand equity", Journal of Product and Brand Management, Vol. 24 No. 5, pp. 449-461.

Fournier, S. (1998), "Consumers and their brands: developing relationship theory in consumer research", Journal of Consumer Research, Vol. 24, pp. 343-373.

Frank, P. and Watchravesringkan, K. (2016), "Exploring antecedents and consequences of young consumers' perceived global brand equity", Journal of Product and Brand Management, Vol. 25 No. 2, pp. 160-170.

Gendel-Guterman, H. and Levy, S. (2017), "Consumer response to private label brands' negative publicity: a relational effect on retailer's store image", Journal of Product and Brand Management, Vol. 26 No. 2, pp. 204-222.

Geuens, M., Weijters, B. and de Wulf, K. (2009), “A new measure of brand personality”, International Journal of Research in Marketing, Vol. 26 No. 2, pp. 97-107.

Giovanis, A. (2016), "Consumer-brand relationships' development in the mobile internet market: evidence from an extended relationship commitment paradigm", Journal of Product and Brand Management, Vol. 25 No. 6, pp. 568-585.

Guzmán, F., Paswan, A. and Van Steenburg, E. (2015), "Self-referencing and political candidate brands: a congruency perspective”, Journal of Political Marketing, Vol. 14 Nos 1/2, pp. 175-199.

Hakala, U., Sjöblom, P. and Kantola, S.P. (2015), "Toponyms as carriers of heritage: implications for place branding", Journal of Product and Brand Management, Vol. 24 No. 3, pp. 263-275.

Harris, F. and de Chernatony, L. (2001), "Corporate branding and corporate brand performance", European Journal of Marketing, Vol. 35 Nos 3/4, pp. 441-456.

Hegner, S.M. and Jevons, C. (2016), "Brand trust: a cross-national validation in Germany, India, and South Africa", Journal of Product and Brand Management, Vol. 25 No. 1, pp. 58-68.

Hegner, S.M., Fenko, A. and Teravest, A. (2017a), "Using the theory of planned behaviour to understand brand love", Journal of Product and Brand Management, Vol. 26 No. 1, pp. $26-41$.

Hegner, S.M., Fetscherin, M. and van Delzen, M. (2017b), "Determinants and outcomes of brand hate", Journal of Product and Brand Management, Vol. 26 No. 1, pp. 13-25.

Hepola, J., Karjaluoto, H. and Hintikka, A. (2017), "The effect of sensory brand experience and involvement on brand equity directly and indirectly through consumer brand engagement", Journal of Product and Brand Management, Vol. 26 No. 3, pp. 282-293. 
Hess, J., Story, J. and Danes, J. (2011), “A three-stage model of consumer relationship investment", Journal of Product and Brand Management, Vol. 20 No. 1, pp. 14-26.

Ho, H.-C., Lado, N. and Rivera-Torres, P. (2017), "Detangling consumer attitudes to better explain cobranding success", Journal of Product and Brand Management, Vol. 26 No. 7, pp. 704-721.

Hollebeek, L.D. and Chen, T. (2014), "Exploring positively- versus negatively-valenced brand engagement: a conceptual model", Journal of Product and Brand Management, Vol. 23 No. 1, pp. $62-74$.

Hook, M., Baxter, S. and Kulczynsk, A. (2018), "Antecedents and consequences of participation in brand communities: a literature review”, Journal of Brand Management, Vol. 25 No. 4, pp. 277-292.

Huber, F., Meyer, F. and Schmid, D.A. (2015), "Brand love in progress - the interdependence of brand love antecedents in consideration of relationship duration", Journal of Product and Brand Management, Vol. 24 No. 6, pp. 567-579.

Hughes, M.Ü., Bendoni, W.K. and Pehlivan, E. (2016), "Storygiving as a co-creation tool for luxury brands in the age of the internet: a love story by tiffany and thousands of lovers", Journal of Product and Brand Management, Vol. 25 No. 4, pp. 357-364.

Indounas, K. and Arvaniti, A. (2015), "Success factors of new health-care services", Journal of Product and Brand Management, Vol. 24 No. 7, pp. 693-705.

Iyer, P.P., Paswan, A.K. and Davari, A. (2016), "Brands, love and family", Journal of Product and Brand Management, Vol. 25 No. 1, pp. 69-83.

Jeon, J.O. and Baeck, S. (2016), "What drives consumer's responses to brand crisis? The moderating roles of brand associations and brand-customer relationship strength", Journal of Product and Brand Management, Vol. 25 No. 6, pp. 550-567.

Jones, C. and Bonevac, D. (2013), "An evolved definition of the term 'brand': why branding has a branding problem”, Journal of Brand Strategy, Vol. 2 No. 2, pp. 112-120.

Kähr, A., Nyffenegger, B., Krohmer, H. and Hoyer, W.D. (2016), "When consumers harm your brand. The phenomenon of consumer brand sabotage", Journal of Marketing, Vol. 80 No. 3, pp. 25-41.

Kapferer, J. (2008), The New Strategic Brand Management, Creating and Sustaining Brand Equity Long Term, Kogan Page, London.

Karjaluoto, H., Munnukka, J. and Kiuru, K. (2016), "Brand love and positive word of mouth: the moderating effects of experience and price", Journal of Product and Brand Management, Vol. 25 No. 6, pp. 527-537.

Kaufmann, H.R., Correia Loureiro, S.M. and Manarioti, A. (2016), "Exploring behavioural branding, brand love and brand co-creation", Journal of Product and Brand Management, Vol. 25 No. 6, pp. 516-526.

Keller, K.L. (1993), "Conceptualizing, measuring, and managing customer-based brand equity”, Journal of Marketing, Vol. 57 No. 1, pp. 1-22.

Keller, K.L. (2016), "Reflections on customer-based brand equity: perspectives, progress, and priorities", AMS Review, Vol. 6 Nos 1/2, pp. 1-16.

Kennedy, E. and Guzmán, F. (2017), "When perceived ability to influence plays a role: brand co-creation in web 2.0", Journal of Product and Brand Management, Vol. 26 No. 4, pp. 342-350.

Kennedy, K. (2017), “I create, you create, we all create - for whom?”, Journal of Product and Brand Management, Vol. 26 No. 1, pp. 68-79.

Kowalczyk, C.M. and Pounders, K.R. (2016), "Transforming celebrities through social media: the role of authenticity and emotional attachment", Journal of Product and Brand Management, Vol. 25 No. 4, pp. 345-356.

Kristal, S., Baumgarth, C., Behnke, C. and Henseler, J. (2016), "Is co-creation really a booster for brand equity? The role of co-creation in observer-based brand equity (OBBE)", Journal of Product and Brand Management, Vol. 25 No. 3, pp. 247-261.

Kucharska, W. and Mikołajczak, P. (2018), "Personal branding of artists and art-designers: necessity or desire?”, Journal of Product and Brand Management, Vol. 27 No. 3, pp. 249-261.
New challenges in brand management

269 
SJME 22,3

Kumar, A. (2018), "Story of Aaker's brand personality scale criticism", Spanish Journal of Marketing ESIC, Vol. 22 No. 2, pp. 203-230.

Leak, R.L., Woodham, O.P. and McNeil, K.R. (2015), "Speaking candidly: how managers' political stances affect consumers' brand attitudes", Journal of Product and Brand Management, Vol. 24 No. 5, pp. 494-503.

Li, F., Xu, L., Li, T. and Zhou, N. (2015), "Brand trust in a cross-cultural context: test for robustness of an alternative measurement model”, Journal of Product and Brand Management, Vol. 24 No. 5, pp. 462-471.

Liu, X., Lischka, H.M. and Kenning, P. (2018), "Asymmetric cognitive, emotional and behavioural effects of values related and performance-related negative brand publicity", Journal of Product and Brand Management, Vol. 27 No. 2, pp. 128-145. No

$\mathrm{Lu}, \mathrm{J}$. and Xu, Y. (2015), “Chinese young consumers' brand loyalty toward sportswear products: a perspective of self-congruity", Journal of Product and Brand Management, Vol. 24 No. 4, pp. 365-376.

Marques dos Santos, J.P., Martins, M., Ferreira, H.A., Ramalho, J. and Seixas, D. (2016), "Neural imprints of national brands versus own-label brands", Journal of Product and Brand Management, Vol. 25 No. 2, pp. 184-195.

Meaningful Brands ${ }^{\circledR}$ (2018), available at: www.meaningful-brands.com/en (accessed 25 September 2018)

Merrilees, B. (2016), "Interactive brand experience pathways to customer-brand engagement and value co-creation", Journal of Product and Brand Management, Vol. 25 No. 5, pp. 402-408.

Mishra, A., Dash, S.B. and Cyr, D. (2014), "Linking user experience and consumer-based brand equity: the moderating role of consumer expertise and lifestyle", Journal of Product and Brand Management, Vol. 23 Nos 4/5, pp. 333-348.

Mitchell, P., King, J. and Reast, J. (2001), "Brand values related to industrial products", Industrial Marketing Management, Vol. 30, pp. 415-424.

Morgan-Thomas, A. and Veloutsou, C. (2013), "Beyond technology acceptance: brand relationships and online brand experience", Journal of Business Research, Vol. 66 No. 1, pp. 21-27.

Nguyen, T.D., Dadzie, C., Davari, A. and Guzmán, F. (2015), "Intellectual capital through the eyes of the consumer", Journal of Product and Brand Management, Vol. 24 No. 6, pp. 554-566.

Osuna-Ramírez, S.A., Veloutsou, C. and Morgan-Thomas, A. (2017), "A systematic literature review of brand commitment: definitions, perspectives and dimensions", Athens Journal of Business and Economics, Vol. 3 No. 3, pp. 305-332.

Palazón, M., Sicilia, M. and López, M. (2015), "The influence of 'Facebook friends' on the intention to join brand pages", Journal of Product and Brand Management, Vol. 24 No. 6, pp. 580-595.

Papadopoulos, N., Hamzaoui-Essoussi, L. and Banna, A.E. (2016), "Nation branding for foreign direct investment: an integrative review and directions for research and strategy", Journal of Product and Brand Management, Vol. 25 No. 7, pp. 615-628.

Park, C.W., Eisingerich, A.B. and Park, J.W. (2013), "Attachment-aversion (AA) model of customerbrand relationships”, Journal of Consumer Psychology, Vol. 23 No. 2, pp. 229-248.

Pasternak, O., Veloutsou, C. and Morgan-Thomas, A. (2017), "Self-presentation, privacy and EWOM in social media”, Journal of Product and Brand Management, Vol. 26 No. 4, pp. 415-428.

Pino, G., Guido, G. and Peluso, A.M. (2015), "Perceived images and vocations of local territorial systems: implications for place branding strategies", Journal of Product and Brand Management, Vol. 24 No. 3, pp. 287-302.

Poulis, A. and Wisker, Z. (2016), "Modeling employee-based brand equity (EBBE) and perceived environmental uncertainty (PEU) on a firm's performance", Journal of Product and Brand Management, Vol. 25 No. 5, pp. 490-503.

Rauschnabel, P.A., Kammerlander, N. and Ivens, B.S. (2016), "Collaborative brand attacks in social media: Exploring the antecedents, characteristics, and consequences of a new form of brand crises", Journal of Marketing Theory and Practice, Vol. 24 No. 4, pp. 381-410. 
Rialti, R., Caliandro, A., Zollo, L. and Ciappei, C. (2018), "Co-creation experiences in social media brand communities: analyzing the main types of co-created experiences", Spanish Journal of Marketing ESIC, Vol. 22 No. 2, pp. 122-141.

Rodhain, A. and Aurier, P. (2016), "The child-brand relationship: social interactions matter", Journal of Product and Brand Management, Vol. 25 No. 1, pp. 84-97.

Rojas-Méndez, J.I. (2013), “The nation brand molecule", Journal of Product and Brand Management, Vol. 22 No. 7, pp. 462-472.

Rojas-Méndez, J.I., Papadopoulos, N. and Alwan, M. (2015), “Testing self-congruity theory in the

New challenges in brand management context of nation brand personality", Journal of Product and Brand Management, Vol. 24 No. 1, pp. 18-27.

Ruane, L. and Wallace, E. (2015), "Brand tribalism and self-expressive brands: social influences and brand outcomes", Journal of Product and Brand Management, Vol. 24 No. 4, pp. 333-348.

Saleem, F.Z. and Iglesias, O. (2016), "Mapping the domain of the fragmented field of internal branding", Journal of Product and Brand Management, Vol. 25 No. 1, pp. 43-57.

Scheidt, S., Gelhard, C., Strotzer, J. and Henseler, J. (2018), "In for a penny, in for a pound? Exploring mutual endorsement effects between celebrity CEOs and corporate brands", Journal of Product and Brand Management, Vol. 27 No. 2, pp. 203-220.

Schultz, D., S.H. (2004), Brand Babble: Sense and Nonsense about Branding, Thomson/South Western.

Schultz, D. (2016), "Market brand equity: lost in terminology and techniques?", Journal of Product and Brand Management, Vol. 25 No. 6, pp. 507-515.

Sheth, J.N., Newman, B.I. and Gross, B.L. (1991), Consumption Values and Market Choice: Theory and Applications, South Western Publishing, Cincinnati.

Siano, A., Vollero, A. and Palazzo, M. (2011), "Role of online consumer empowerment in reputation building", Journal of Brand Management, Vol. 19 No. 1, pp. 57-71.

Simon, C., Brexendorf, T.O. and Fassnacht, M. (2016), "The impact of external social and internal personal forces on consumers' brand community engagement on facebook", Journal of Product and Brand Management, Vol. 25 No. 5, pp. 409-423.

Tafesse, W. (2016), "An experiential model of consumer engagement in social media", Journal of Product and Brand Management, Vol. 25 No. 5, pp. 424-434.

Thomas, R.J. (2015), "Out with the old and in with the new: a study of new kit sponsorship and brand associations in the barclays premier league", Journal of Product and Brand Management, Vol. 24 No. 3, pp. 229-251.

Törmälä, M. and Saraniemi, S. (2017), "The roles of business partners in corporate brand image cocreation", Journal of Product and Brand Management, Vol. 27 No. 1, pp. 29-40.

Ullrich, S. and Brunner, C.B. (2015), "Negative online consumer reviews: effects of different responses", Journal of Product and Brand Management, Vol. 24 No. 1, pp. 66-77.

Urde, M. (2016), "The brand core and its management over time", Journal of Product and Brand Management, Vol. 25 No. 1, pp. $26-42$.

Vallaster, C. and von Wallpach, S. (2013), "An online discursive inquiry into the social dynamics of multi-stakeholder brand meaning co-creation”, Journal of Business Research, Vol. 66 No. 9, pp. 1505-1515.

Vashisht, D. and Pillai, S. (2017), "Are you able to recall the brand? The impact of brand prominence, game involvement and persuasion knowledge in online - advergames", Journal of Product and Brand Management, Vol. 26 No. 4, pp. 402-414.

Veloutsou, C. (2007), "Identifying the dimensions of the product-brand and consumer relationship", Journal of Marketing Management, Vol. 23 Nos 1/2, pp. 7-26.

Veloutsou, C. (2009), "Brands as relationship facilitators in consumer markets", Marketing Theory, Vol. 9 No. 1, pp. 127-130. 
Veloutsou, C. (2015), "Brand evaluation, satisfaction and trust as predictors of brand loyalty: the mediator-moderator effect of brand relationships", Journal of Consumer Marketing, Vol. 32 No. 6, pp. $405-421$.

Veloutsou, C. and Guzmán, F. (2017), "The evolution of brand management thinking over the last 25 years as recorded in the journal of product and brand management", Journal of Product and Brand Management, Vol. 26 No. 1, pp. 2-12.

Veloutsou, C. and McAlonan, A. (2012), "Searching on the internet: what will make teenagers loyal to a search engine?”, Journal of Consumer Marketing, Vol. 29 No. 2, pp. 125-135.

Veloutsou, C. and Moutinho, L. (2009), "Brand relationships through brand reputation and brand tribalism”, Journal of Business Research, Vol. 62 No. 3, pp. 314-322.

Veloutsou, C. and Panigyrakis, G. (2001), "Brand teams and the brand management structure in pharmaceutical and other fast moving consumer goods companies", Journal of Strategic Marketing, Vol. 9 No. 3, pp. 233-251.

Veloutsou, C. and Taylor, C. (2012), "The role of the brand as a person to business to business brands", Industrial Marketing Management, Vol. 41 No. 6, pp. 898-907.

Veloutsou, C., Christodoulides, G. and de Chernatony, L. (2013), "A taxonomy of measures for consumer-based brand equity: drawing on the views of managers in Europe", Journal of Product and Brand Management, Vol. 22 No. 13, pp. 238 -248.

Vernuccio, M., Pagani, M., Barbarossa, C. and Pastore, A. (2015), "Antecedents of brand love in online network-based communities: a social identity perspective", Journal of Product and Brand Management, Vol. 24 No. 7, pp. 706-719.

Walker, K. (2010), "A systematic review of the corporate reputation literature: definition, measurement, and theory", Corporate Reputation Review, Vol. 12 No. 4, pp. 357-387.

Wallace, E., Buil, I. and de Chernatony, L. (2014), "Consumer engagement with self-expressive brands: brand love and WOM outcomes", Journal of Product and Brand Management, Vol. 23 No. 1, pp. 33-42.

Walsh, G. and Beatty, S. (2007), "Customer-based corporate reputation of a service firm: scale development and validation", Journal of the Academy of Marketing Science, Vol. 35, pp. 127-143.

Yousaf, S. and Li, H. (2015), "Social identity, collective self-esteem and country reputation: the case of Pakistan", Journal of Product and Brand Management, Vol. 24 No. 4, pp. 399-411.

Zarantonello, L., Romani, S., Grappi, S. and Bagozzi, R.P. (2016), "Brand hate", Journal of Product and Brand Management, Vol. 25 No. 1, pp. 11-25.

Zarantonello, L., Romani, S., Grappi, S. and Fetscherin, M. (2018), "Trajectories of brand hate”, Journal of Brand Management, available at: https://doi.org/10.1057/s41262-018-0105-5

\section{Further reading}

Halaszovich, T. and Nel, J. (2017), "Customer-brand engagement and facebook fan-page 'like'intention", Journal of Product and Brand Management, Vol. 26 No. 2, pp. 120-134.

Radler, V.M. (2018), "20 Years of brand personality: a bibliometric review and research agenda", Journal of Brand Management, Vol. 25 No. 4, pp. 370-383.

\section{Corresponding author}

Cleopatra Veloutsou can be contacted at:Cleopatra.Veloutsou@glasgow.ac.uk

For instructions on how to order reprints of this article, please visit our website:

www.emeraldgrouppublishing.com/licensing/reprints.htm

Or contact us for further details: permissions@emeraldinsight.com 